\title{
Legitimation Development of the Judicial Liability System for Chinese Judges in the Context of Judicial Reform
}

\author{
Jun Meng \\ Law School \\ Beijing Normal University \\ Beijing, China 100875
}

\begin{abstract}
Judicial liability system of judges is one of the important parts of Chinese judicial reform. Judicial accountability of judges is to enhance judges' credibility, safeguard judicial authority, at the same time, the relationship between judicial independence and judicial responsibility shall be settled successfully. After judicial changes, the basic principles, main contents and accountability procedures of the judicial liability system of Chinese judges have undergone major changes. The new judicial liability system of judges stresses that accountability of judges shall follow rules of justice, and has presented the judgment criteria of paying equal attention to both the results and behavior for judges' responsibility. Accountability procedures have reflected a certain degree of justice, and the judicial liability system of judges is developing towards legitimation in the context of judicial reform. Reform of judicial liability system of judges needs the establishment of supporting system.
\end{abstract}

Keywords-judicial reform; judges' responsibility; accountability procedures; legitimation

\section{INTRODUCTION}

Justice is one of the main methods of social governance, and it maintains normal functioning of society through distribution and rectifying of social justice. Justice is inseparable from the judicial subjects, and judicial behavior is the action that judicial subjects conducted to resolve legal disputes following the legal procedures. Acting as subjects of judicial behavior, judges are the core of judicial power operation. Judicial behavior is a kind of power behavior, and judges exercise judiciary power on behalf of the State, which power is of final definitive effect on judgment of disputes, and the result of judgment is mandatory with no organ or individual is entitled to change. The exercise of power is accompanied by constraints on power, which has become a principle to operate state system. The authority attribute has determined that it is necessary to limit judicial behavior appropriately to avoid power abuse of judges. Judicial responsibility is an effective mechanism to avoid unrestrained judicial power and differentiation, and to promote correct execution of judicial power within a reasonable range, setting a direction for the judicial behavior of judges. Judges' judicial power is consistent with their judicial responsibility, as there is no responsibility without power, and there is no power without responsibility, both of them form a unity within judicial behavior. Judicial behavior is a distribution of benefits, involving allocation of rights and obligations of citizens, as well as the deprivation of property, liberty or even life of citizens. The main duties of judges are to ascertain the facts relying on evidence and following the legal procedures, to mediate disputes, and make a fair and reasonable judgment. If misjudged cases or even judicial corruption appear due to the fault of the judge's subjective fault and objective behavior, the litigant's legitimate rights and interests will be directly damaged, and the authority and impartiality of the national judicial system will also be seriously damaged. "Even if a system is useful and helpful in general, it is not a panacea, and there is no system without shortcomings. A system will not always be correct in terms of specific issues, and sometimes it will even result in major error in historical judgment." ${ }^{(1)}$ Conduct a certain degree of restriction on judges' judicial behavior, and present warning for the results of judicial behavior, will be beneficial to the supervision of judges' official behavior and professional ethics, so as to minimize misjudged cases. Judicial behavior theory suggests that judicial responsibility is one of the core controlling elements to control the abuse of judicial power by judicial subjects. A sound responsibility system of the judges is an effective way to eliminate the illegal judicial action by the judges, to curb judicial corruption and to realize judicial independence and justice.

As the executor of national jurisdiction, judges possess the unique professional ethics and professional spirit, with the duty to allocate rights and obligations between the litigants, in order to achieve national judicial power. The awards given by judges will directly affect the litigants' interests and the order in their social life. Therefore, the judges are responsible for the rewards given by them while exercising judicial power, which is in line with the principle of "clear rights and liabilities" and "judicial supervision". But judges follow the principle of judicial independence, which has a unique method of evidence deduction and factual inference, to make final award about the cases. As a result, how to deal with relationship between judicial independence

(1) Su Li: How Systems Are Formed, Peking University Press, 2007, P55 
and judicial responsibility, what kind of judicial responsibility the judges shall assume, and how to investigate the judicial responsibility of judges has always been the major concern.

\section{Changes OF CHINESE JUdicial Liability SYSTEM OF JUDGES IN THE CONTEXT OF JUDICIAL REFORM}

The judge accountability system is not formed in the modern time from a perspective of historical development, as there is a saying of "Unjust Verdict" in Chinese ancient times for the judges to deal with cases. Namely, the judge will commit a crime and be hold accountable if he pronounced an innocence one guilty or acquitted a criminal of the crime. The purpose of this system is to avoid illegal judgment by the judges, with its main function of punishing or deterrence to the judicial behavior of judges. The deterrence principle may be the main principle of traditional judicial accountability of judges, which is also influencing the contemporary Chinese accountability system of judges.

Before 1992, there is no unified system for judicial accountability of judges in China, the contents about judges to assume responsibility for judgment are scattered in "Judges Law of the People's Republic of China" and the evaluation mechanism of judges' work. The responsibility scope of judges and accountability procedures are not clear. Supreme People's Court proposed "accountability system of misjudged cases" for the first time in 1992, and the judicial responsibility of judges was listed in system. But various parties have always been controversial about the definition of misjudged cases and whether or nor the judges shall take responsibility for the misjudged cases. There exists the practice to determine the judge's responsibility just rely on the result as well as the system with main purpose of deterrence to a judge for his responsibility of misjudged cases. Supreme People's Court developed "Accountability Method of Illegal Judicial Responsibility of People's Court Judges (Trial)" in 1998, changing "misjudged case accountability" to "illegal judgment responsibility." The method has determined the scope of responsibility a judge shall assume, stipulating that the accountability procedures shall be managed by the supervision departments inside the court, reflecting the administrative treatment of holding a judge accountable.

China launched a new round of judicial reform in 2008, taking the public's needs of justice as a base point, and presenting specific reform tasks around optimizing distribution of judicial functions and powers, strengthening the construction of judicial contingent, intensifying judicial financial security, improving the judicial responsibility system and other aspects. In the process of Chinese judicial reform, to reform and improve the judicial accountability is one of its important parts. Supreme People's Court issued "Opinions on Establishing and Strengthening a Working Mechanism to Prevent Criminal Misjudged Cases" against the phenomenon of frequent criminal misjudged cases in China in November 21, 2013, putting forward the guiding opinions on prevention of criminal misjudged cases, proposing instructive comments on prevention of criminal misjudged cases and to establish and strengthen the responsibility system of case-handling with parity of authority and responsibility of the judges, so as to better regulate criminal judicial procedure and to prevent occurrence of criminal misjudged cases. "The Chinese Communist Party Central Committee's Decision on a Number of Major Issues Relating to Comprehensively Implementing Governing the Country by Law" passed in the fourth plenary session of the eighteenth central committee in 2014 proposed "promote strict justice, adhere to taking facts as basis and taking law as the criterion, push lawsuit system reform with the judgment as a center, perform lifelong guarantee for case handling quality and check back accountability of misjudged cases" to determine the policy direction for this new round of judicial reform in the judicial liability system. The Supreme Court issued "Several Opinions on Improving Judicial Liability System of People's Court" (hereinafter referred to as "Opinions on Judicial Liability System") in 2015, making clear regulations on such aspects as the target and principle of judicial liability system of the court system, operation mechanism of judgment power, responsibility and authority of judicial officers, identification and investigation of judgment responsibility, security of judges for them to perform duties. There are new changes about regulation on judicial liability system appeared in the new round of judicial reform, which changes contain both the evolution of system contents and the update of judicial philosophy. "Opinions on Judicial Liability System" has become the criteria for identification and investigation of current Chinese judicial responsibilities of judges. Yet there is space for further discussion on the specific content of these opinions, such as the scientific setting of the judgment responsibility and authority of a judge, composition and operational procedures of Judge Disciplinary Committee. In addition, a legal system alone is difficult to play its role effectively, which system must be placed in a certain institutional space, to play the function of judicial liability system of judges in the association and coordination with other systems.

\section{JUDGES JUdICIAL ACCOUNTABILITY PRINCIPLE: \\ FROM PURE DETERRENCE TO FOLLOW LAW OF JUSTICE}

Accountability system of misjudged cases emphasizes strict accountability of the misjudged case results caused by judges, taking deterrence as main action in terms of system functions, to alert judges to impartially exercise the judicial power. The occurrence of misjudged cases have complex reasons, containing personal factors of the judge, and complexity of the case itself, only limited evidence can be collected, as well as the limitations of the judicial system itself and other reasons. The judge's behavior of a judgment is a judicial behavior, which has a set of judicial laws to follow, and the judicial accountability of judges shall also follow this law. In 2015, Article 2 of "Opinions on Judicial Liability System" stipulates that People's Court shall follow the following basic principles to promote reform of judgment liability system: exercise judicial power independently in accordance with the Constitution and laws; follow the operation rules of judicial power, reflecting the property of judgment and decision rights of judicial power, and highlighting the dominant position of case handling of the 
judges; take judicial power as the core, and take the judgment supervision rights and judgment management rights as guarantee etc. This Article has made clear that judicial accountability of judges shall take judicial systems into comprehensive consideration and follow law of justice, changing the tendency of judges' judicial accountability which lays emphasis on deterrence function.

\section{A. Judicial Independence and Judicial Accountability of Judges}

Judicial independence is one of the fundamental principles of judicial activity. First of all, judicial independence is a constitutional principle, and the principle of judicial independence is generally recognized by national constitutions. The Constitution is the fundamental law of the country with the highest legal effect in a country's legal system. So any other law must take it as a basis, and judicial practice must also comply with it, therefore, constitutional norm shave become basic norms of judicial activities. Judicial independence is an organizing principle, and to ensure the independence of judicial power, first of all there shall be a guarantee which is the independence of the judicial authority. Independence of judicial authority organization include to implement special qualification and selection system as well as judicial exemption system on judicial officers, and the guarantee of independent working funds for judicial authority. Judicial independence is also a working principle. In the administration of justice, the judicial authority exercise judicial power independently without any external power to interfere except those in accordance with laws, and it is always independent in the course of exercising judicial power. Judicial officers are independent in the course of exercising judicial power, and they are independent while dealing with cases relative to their colleagues, superiors and the judicial authority they belong to. They have independent authority without any control or intervention from their colleagues, superiors or the judicial system they belong to. Judicial independence is the premise and foundation for judges to assume responsibility. If a judge has no independent jurisdiction, then it will be unreasonable to make the judge assume responsibility for the judgment results. On the other hand, independent exercise of judicial power by judges may be influenced by the scientificity of the content and program setting for judicial accountability of judges. If the design of judicial liability system is unreasonable, judges may be unwilling or avoid exercising judicial power independently in order to avoid being held accountable. The construction of judicial liability system in Chinese judicial reform includes two constituent elements: First, "Let the inquisitor make judgment," and second "make the judges shoulder responsibility." (2) The former emphasizes the independent behavior of a judge to conduct the act of hearing, which plays a substantive role in the judgment results; the latter emphasizes the judges shall be responsible for the cases they dealt with. Judicial guarantees, judicial supervision and judicial accountability shall be implemented, and a scientific disciplinary system of judge shall be

\footnotetext{
(2) Jiang Huiling: Specific Problems Facing by Future Judicial System Reform [M], Caijing Magazine, Dec. 1, 2013
}

established in future judicial reform on the basis that judges independence is guaranteed and responsibility boundaries are determined. ${ }^{(3)}$ Judicial independence is of significant meaning for judges' judicial accountability. On the one hand, judges are legally entitled to conduct a separate trial, and judge is the subject of a trial who is only responsible for law with objectivity, neutrality of judicial act without any intervention from other government agencies and organizations; On the other hand, the judge should and can assume full responsibility for their judicial behavior which is not based on deterrence theory, but the organic unity of judicial behavior of judicial responsibility of judges on the premise of judicial independence.

\section{B. Trial-Centered and Judge Accountability}

As for criminal proceedings, the criminal accountability of the offender is carried out in phases in China, and a complete litigation procedure includes filing, investigation, prosecution, trial, execution. Trial centralism refers to, as for the relationship between various stages of criminal proceedings, taking criminal trial stage as the center of the whole criminal proceedings, and investigation, prosecution and other pre-trial proceedings are considered as the preparatory phase of trial proceedings; The legitimate rights and interests of litigant participants can only be safeguarded fully, and the criminal responsibility of the accused can only get the final and authoritative determine at the trial stage. Trial centralism means that the entire litigation system and activities shall be constructed and launched around the trial. Trail stage has a substance-oriented feature in terms of investigation of the trail; investigation is the preparation for trial activities; prosecution is the activity for starting the judicial proceedings; execution is to implement the judgment results; the complaint, defense and trial form the central structure of litigation. ${ }^{(4)}$ Construction of trail-centered system is the basis of judges' judicial accountability. Substantive review of the case is formed in the trial stage, and the judge's judicial behavior contributes to the formation of final awards, and if judicial behavior error of judges occurs in this process, the judge shall be hold accountable logically. If the structure of proceedings is not trial-centered but investigation-centered then the substantive investigation and comprehensive investigation of the case are all formed in the investigation stage; and judicial behavior of judges is to control the quality of a case without substantial function, then the judicial accountability mainly against judges is unreasonable. Misjudged case is formed in the investigation stage, and the judges have no enough procedural mechanisms to correct. Put the responsibility of misjudged case on judges can not achieve the fundamental purpose of judicial accountability. The traditional Chinese criminal procedure structure is precisely investigation-centered, and the trial mode of "taking file record as a center" exists in the criminal trail, and the trail is conducted around the files formed in the

\footnotetext{
(3) Xu Xin, Huang Yanhao, Wang Xiaotang: Annual Report on Chinese Judicial Reform 2014, Tribune of Political Science and Law, 2015, Vol.3

(4) Zhang Jianwei: Essence and Appearance of Judgement Centralism, People's Court Daily, June 20, 2014
} 
investigation stage. ${ }^{(5)}$ Trial centralism is proposed in current judicial reform, which is the return of scientific understanding on the trial to follow the law of justice. The criminal proceedings system reform with the trail as a center shall realize "taking trail as the center" in terms of macro relationship of investigation, review and trial; establish authority of first instance in terms of factual finding in the longitudinal direction on the basis of solid foundation of first instance. ${ }^{6}$ Taking trial as a center highlights the dominant position of judges in dealing with the cases. The judgment of judges has become the focus of the judicial process, which laid the litigation system foundation for the establishment of judges' judicial accountability system.

\section{JUDGES JUDICIAL ACCOUNTABILITY CONTENTS: FROM FOCUS ON RESULTS TO PAY EQUAL ATTENTION TO BEHAVIOR AND RESULTS}

The standard for judges to assume judicial responsibility is the core content of judges' judicial accountability. Some scholars divide the judicial liability system of judges into three modes: First, results responsibility mode, namely the system mode for holding the judge who has made a mistake in the judgment of a case accountable; the second is procedural responsibility mode, namely the system mode to hold a judge accountable if procedure illegal behavior exist in the course of trail and has resulted in serious consequences. Third, professional ethics responsibility mode, namely a judge shall be hold accountable due to violation of professional ethics. ${ }^{8}$ Supreme People's Court proposed the "accountability system of misjudged cases" for the first time in 1992, various parties have always been controversial about understanding of misjudged cases. The reference of "misjudged case" itself pays attention to the result of the case. Chinese judges judicial accountability is identical to the misjudged case accountability for a period of time, and whether or not the judge shall be hold accountable for case handling is determined by whether or not the actual judgment result has been changed. Misjudged case accountability with judgment result as a standard has once existed in some provisions on misjudged case enacted by district court and the evaluation mechanism of court in China. Article 2 of "Accountability Method of Illegal Judicial Responsibility of People's Court Judges (Trial)"formulated by Supreme People's Court in 1998 stipulates that judicial officers of people's court shall be hold accountable for illegal judgment for their deliberate violation of the laws and regulations relating to trial, or the negligent violation of the laws and regulations relating to trial in course of trial and implementation which has resulted in serious consequences. According to the provision of this Article, "illegal judgment responsibility" will be formed if the following factors are met: First, the judge has the intentional or grossly negligent subjectively; second, the judge has violated relevant laws

\footnotetext{
(5) Chen Ruihua: Three Modes of Judge Liability System, Chinese Journal of Law, 2015, Vol. 4

(6) Wei Xiaona: Trail-Centered Criminal Procedure System Reform, Chinese Journal of Law, 2015, Vol. 4

${ }^{8}$ Chen Ruihua: Centralism Files and Notes---Review on China's Criminal Trial Mode, Chinese Journal of Law, 2006, Vol. 4
}

and regulations; Third, serious consequences have caused. A judge can only be hold accountable for illegal judgment responsibility when the three conditions are met simultaneously. This provision takes the procedural violation by a judge and serious consequences have been caused a standard to hold a judge accountable for judgment responsibility. Compared with the result responsibility mode, procedures responsibility mode has introduced in procedure violation factors, changing the situation of simply determining the judge to assume responsibility if the judgment results of the case. Article 25 of "Opinions on Judicial Liability System" issued by Supreme People's Court in 2015 stipulates that in the course of conducting a trial, a judge shall be hold accountable for illegal judicial responsibility if he has violated the laws and regulations deliberately, or a judgment error is caused due to his gross negligence and has resulted in serious consequences. According to this provision, a judge shall be hold accountable for illegal judicial responsibility if he has procedural violation behavior or improper behavior and has caused serious consequences. Article 26 stipulates the specific causes to hold a judge accountable for illegal judicial responsibility: 1. the behaviors of embezzlement, bribery, favoritism, perverting of law exist in dealing with the cases; 2.dealing with the cases by himself against the provisions or creating false cases; 3.altering, concealing, falsifying, substitution and intentional destruction of evidence, or loss or destruction of evidence due to gross negligence and serious consequences have been caused; 4 . Concealing the main evidence, important plot and intentionally providing false materials when reporting cases to collegial panel or judicial committee, or missing of important evidence and plot because of gross negligence, resulting in judgment errors and serious consequences; 5.intentionally violate collegiate bench result and the decision of judicial committee when preparing litigation documents, or judgment document error due to gross negligence and has resulted in serious consequences; 6.offer abatement from penalty and conditional release to the offenders who do not meet the conditions thereof in violation of the law, or offer abatement from penalty and conditional release to the offenders who do not meet the conditions thereof due to gross negligence and has caused serious consequences; 7.other intentional breach of legal procedure, rules of evidence and illegal judgment clearly stipulated by law, or judgment error due to gross negligence has caused serious consequences. Wherein Item 1 and Item 2 take violation of law as the standard to determine whether or not a judge shall assume illegal judicial responsibility, regardless of the final results the cases; Item 3, Item 4 and Item 5 take the behavior and results as standard to determine whether or not a judge shall assume illegal judicial responsibility; Item 6 takes judge's illegal behavior or improper behavior and whether or not serious consequences have been caused as standard to determine whether or not the judge shall bear illegal judicial responsibility against the cases of abatement from penalty and conditional release. Compared with the provisions issued by Supreme People's Court in 1998, the provisions issued in 2015 are more flexible and targeted in setting different standards for determining a judge's judicial 
responsibility against different judicial matters. Meanwhile, Article 25 stipulates that a judge shall be treated separately in accordance with laws and regulations relating to discipline, if he has such illegal and undisciplined behaviors as violation of professional ethics and disciplinary regulations, accepting the banquet or gifts offered by litigants and related personnel, conducting improper association with lawyers. Thus professional ethics responsibility mode is not a core component for current Chinese judges to assume judicial responsibility.

As previously mentioned, the causes for misjudged case are complex. There are uncertainties in operation of laws, thus it is necessary to distinguish clearly which misjudged results are caused by judges, or to determine the judge has broken the law. It can be seen from the changes and development of Chinese judges judicial accountability content that, the judge judicial accountability standards have experienced a shift from inner subjective fault to outer inappropriate behavior, and from fairness of substantive results to legitimate of process. ${ }^{8}$ It is difficult to determine the judge's subjective intent or negligence sometimes in the process of case handling, while outer behavior is visible and tends to form judicial instruments. It is difficult to find an absolute objective criterion to determine whether or not the substantive judgment of case is fair, while complying with legal procedures is indeed the uniform requirements for all judges. Because it is difficult to determine whether or not the substantive judgment of case is fair, thus procedural fairness of the case has a great significance. From the perspective of substantive sense, social justice itself is full of value judgments, reflecting judge's subjective intent. Therefore, just from the perspective of substantive meaning, there is little possibility for the result of case to obtain people's full agreement. However, from the perspective of procedural meaning, as long as people comply with the procedures commonly agreed in advance, they shall accept the awards made through such procedures after case handling, thus the judgment made under such condition is legitimate, and then it can be said correct. (9)"Legitimacy of a judge's behavior can provide legitimacy for the fairness of the awards made by a judge." ${ }^{(10}$ If a judge's behavior is legitimate, he shall not be held accountable even though the case result is wrong, and original results changed by follow-up program shall not be taken as a basis to hold a judge accountable. Result liability mode can promote the judge to handle cases according to law and in justice to a certain extent, but it has great limitations, as it has cut the judge judicial independence, violating the basic law of judicial system. If judicial accountability is limited to the results-oriented thinking of "misjudged case accountability", "trial flaws accountability" or "lifelong guarantee of case handling", then it is still difficult to avoid unbalance in rights and liabilities caused by

\footnotetext{
${ }^{8}$ Wei Shengqiang: Origin and Future of Misjudged Case Accountability -Thinking On System of Chinese Judge Liability Accountability, Law Science, Sept. 2012

(9) Yan Renqun: Important Points of American System of Judicial Punishment and Discipline, Law Review, 2004, Vol. 6

(10) Sun Xiaoxia: Governance on Legal Personnel--Reflection on Chinese Legal Profession, China University of Political Science and Law Press, 2005, P.233
}

asymmetry of judicial information. ${ }^{11} \mathrm{With}$ respect to the pure result standard, the standard of behavior and results is more scientific and rational, and fits the actual judge judicial accountability better. The transformation of judges' judicial accountability standards has taken into account the balance between judicial independence and judicial responsibility, but also indicates the return of understanding of judges judicial accountability to judicial law in the Chinese judicial reform.

\section{PROCEDURE OF JUdGES JUdICIAL ACCOUNTABILITY: FROM ADMINISTERIZATION TO JUDICIALIZATION}

Complete judicial liability system of judges includes such aspects as the principle of judicial liability accountability, contents of judicial liability accountability, and procedures of judicial accountability. A perfect judicial liability accountability procedure is a guarantee to implement the judicial liability accountability system.

\section{A. Subject of Judges Judicial Accountability}

From the legislative pattern of other countries, it can be seen that the subjects of judges liability accountability are not uniform, as some are carried out by legislative body, some by the judiciary itself, some set up a special committee, such as judges disciplinary committee. The similarity of these practices are that judges judicial liability accountability is dominated by the agency of higher legal rank, on the one hand, it shows the careful discipline of judges, on the other hand it is to ensure the unity and authority judges judicial liability accountability. Article 28 of "Accountability Method of Illegal Judicial Responsibility of People's Court Judges (Trial)" issued by the Supreme Court in 1998 stipulates that supervision departments of people's court at all levels are the functional departments to investigate illegal judgment responsibility, and they are responsible for collecting clues, investigating illegal judgment responsibility and handling of responsible person in accordance with relevant regulations. According to this Article, the subject of judges' liability accountability is the supervision department of courts. Supervision departments are established inside the court, and the nature of power execution is similar to administrative power. It can be seen that the subject setting of then Chinese judges' liability accountability is basically in accordance with the responsibility investigation mode of civil servants in administrative organs. Article 34 of "Opinions on Judicial Liability System" issued by Supreme People's Court in 2015 stipulates that if an illegal judgment responsibility needs to be investigated, generally the preliminary comments shall be proposed by the president, trial supervision department or trial management department. And the trial supervision department shall be delegated by the president to review or submit to the judicial committee for discussion. If the relevant personnel are confirmed preliminarily of having the situation of illegal judgment accountability listed in this Opinion through review, then the supervision department of the court shall start illegal judgment accountability

${ }^{11}$ Chen Hangping: Between Judicial Dependence and Responsibility-Survey and Analysis on Examination and Assessment System of Judges of American States, Contemporary Law Review, 2015, Vol. 5 
procedures. Article 36 stipulates that after the investigation conducted by the people's court supervision department, if someone shall be hold accountable for judges illegal judgment responsibility, it shall be submitted to the President for decision and be submitted to Judges Disciplinary Committee at provinces (autonomous regions and municipalities) for consideration. Based on these provisions, the decentralized mechanism is adopted for subject of judges judicial liability accountability, and the supervision department of the court is responsible for initiating the judicial liability accountability procedures, and the judges disciplinary committee has the right to make a judgment, changing the previous mechanism of judicial liability accountability dominated by supervision department of the court. Court supervision department is located in the interior court with administrative working nature. Judges Disciplinary Committee is at the province (autonomous regions and municipalities) level and detached from specific court. Although the "Opinions on Judicial Liability System" haven't clearly stipulated the composition and working procedures of the judges disciplinary committee, but it can be expected that the working mode of judges disciplinary committee is undoubtedly different from that of the supervision department inside the court.

Unlike the executive staff, the case handling behavior of judges is of judicial attributes. The subject which is responsible for investigation and discipline of judges is no longer administration department inside the court, but the specific disciplinary committee of judges, highlighting the particularity of the judicial behavior of judges, showing the prudence in accountability of judges' matters. The system of judge disciplinary committee proposed by the State is certainly a reflection of judicial objective laws and significant reform initiatives, but it still need careful consideration on specific institutional arrangements. Otherwise, reform effort will be easily absorbed by "systematic" power under the effect of "path dependence". ${ }^{12}$ Judges Disciplinary Committee should be set up following the principle of independence, authority, unifying, avoid affected by other factors in judging judges judicial responsibilities; judges disciplinary committee shall be made with a broader representation to involve in relevant personnel in various aspects, ensuring objectivity and impartiality of judges judicial liability accountability; specific work program of judges disciplinary committee shall reflect justice, and fully listen to the views of the mover and the judge to be held accountable.

\section{B. Judges Judicial Liability Accountability Program}

Overall, the judges judicial liability accountability procedures can be divided into two: one for administrative procedures, and the judicial liability accountability agency shall be responsible for starting, investigation and decision of judicial accountability procedures, while the judge to be held accountable is in a passive position who shall provide assist in the investigation; one for judicial procedures, with the joint participation of judicial liability accountability mover

12 Ma Changshan: Possibility and Limitation of New Round Judicial Reform, Tribune of Political Science and Law, 2015, Vol.5 and the judge to be hold accountable to submit evidence to each other and debate with each other, the judicial liability accountability agency shall make final judgment which is usually presented as hearing procedure. The "Accountability Method of Illegal Judicial Responsibility of People's Court Judges (Trial)" issued by the Supreme Court in 1998 stipulates that the supervision departments of people's courts at all levels are the functional departments for illegal judgment liability accountability, and are responsible for the collection of clues, investigation of illegal trial and handling of responsible personnel in accordance with relevant provisions. Such practice of judges' liability accountability procedure dominated by supervision department inside the court is a typical administrative processing mode. Article 35 of "Opinions on Judicial Liability System" issued by Supreme People's Court in 2015 stipulates that supervision department of the people's court shall conduct investigation on whether or not a judge has illegal judgment behavior, and take the necessary and reasonable measures for protection. During the investigation, the litigants shall be entitled to be informed, to make explanations and provide evidences. Supervision department shall record the opinions, explanations and evidences of the judge to be hold accountable truthfully, and make clarification on whether or not to adopt them in investigation reports. Article 36 stipulates that the supervision department of High People's Court shall sent relevant personnel to the Judge Disciplinary Committee to make report on the illegal judgment facts of the judge to be hold accountable and the proposed processing recommendations and basis, and to present evidences on his illegal judgment behavior and subjective fault. The litigant is entitled to make statement, provide proof and explanations, and apply for reconsideration and appeals. Provisions of Year 2015 has reflected to some extent the justice of judges judicial liability accountability procedures, and structure of investigators, litigants and the judge has been established in terms of procedure setting. As for protection of rights, a series of rights such as making a statement, providing proof and explanations and relief enjoyed by the litigant has been proposed, indicating the respect and protection of a judge's status and rights even he is in investigation.

The administrative procedure of judicial liability accountability is to punish the judge with a kind of administrative structure of accountability means, in essence, it is to resolve judicial power limitation through administrative means. But it has such disadvantages as unable to fully reflect fairness of the accountability process and may damage judge judicial independence directly. Judicial procedures of judicial accountability are to regulate judicial behavior of judges through judicial punishment means, and at the same time to ensure judicial independence of judges and the court. Establishment of judges' management system in accordance with characteristics of judicial power itself is the basic requirement of judicial power operation. "Opinions on Judicial Liability System" issued in 2015 hasn't made clear regulations on specific procedures of judges judicial liability accountability, and the specific programs still need to be refined in the future, involving the procedures of start up, investigation, hearing 
and relief of judges judicial liability accountability, with the core as highlighting justice of the procedures.

\section{CONCLUSION}

The establishment of judicial liability accountability of judges is to regulate judicial behavior of judges, to achieve scientific operation of judge's judicial power, and the fundamental purpose of judicial liability system is to achieve judicial authority and to enhance public confidence in justice. As an important part of China's current judicial reform, the construction of judges' judicial liability accountability is constantly changing, developing from formulating of system objectives, to arrangements of system contents, and to implement the program design. The overall development direction is toward justice law and legitimation of judge judicial liability accountability.

The scientific setting and effective functioning of judges' judicial liability accountability is inseparable from the corresponding supporting mechanisms. Clear judge's responsibilities, the relationship between judges and judicial organization, security for judges to perform duties and other are closely related to the system of judges' judicial liability accountability, but also directly affect smooth implementation of this system. How to combine the system of judges' judicial liability accountability with judge quota system reform as well as the judgment-centered litigation reform is the realistic problem facing by system reform of judges judicial liability accountability in the context of judicial reform. Currently, the judges' judicial liability accountability procedure is still a framework structure, and the power structure and composition as well as the modes of judges' liability accountability still need to be cleared and refined. In addition, whether or not the implementation of lifelong responsibility for case handing quality and misjudged cases check-back accountability stressed in many judicial reform documents is scientific is also need to be explored further.

\section{REFERENCES}

[1] Su Li: How Systems Are Formed, Peking University Press, 2007, P55

[2] Jiang Huiling: Specific Problems Facing by Future Judicial System Reform [M], Caijing Magazine, Dec. 1, 2013

[3] Xu Xin, Huang Yanhao, Wang Xiaotang: Annual Report on Chinese Judicial Reform 2014, Tribune of Political Science and Law, 2015, Vol.3

[4] Zhang Jianwei: Essence and Appearance of Judgement Centralism, People's Court Daily, June 20, 2014

[5] Chen Ruihua: Three Modes of Judge Liability System, Chinese Journal of Law, 2015, Vol. 4

[6] Wei Xiaona: Trail-Centered Criminal Procedure System Reform, Chinese Journal of Law, 2015, Vol. 4

[7] Chen Ruihua: Centralism Files and Notes---Review on China's Criminal Trial Mode, Chinese Journal of Law, 2006, Vol. 4

[8] Wei Shengqiang: Origin and Future of Misjudged Case Accountability --Thinking On System of Chinese Judge Liability Accountability, Law Science, Sept. 2012

[9] Yan Renqun: Important Points of American System of Judicial Punishment and Discipline, Law Review, 2004, Vol. 6
[10] Sun Xiaoxia: Governance on Legal Personnel--Reflection on Chinese Legal Profession, China University of Political Science and Law Press, 2005, P.233

[11] Chen Hangping: Between Judicial Dependence and Responsibility-Survey and Analysis on Examination and Assessment System of Judges of American States, Contemporary Law Review, 2015, Vol. 5

[12] Ma Changshan: Possibility and Limitation of New Round Judicial Reform, Tribune of Political Science and Law, 2015, Vol.5 